\title{
Tillering Capacity of Brachiaria Cultivars in the Brazilian Semi-Arid Region During the Dry Season
}

\author{
E. L. L. Véras ${ }^{a}$, G. S. Difante ${ }^{a}$, A. L. C. Gurgel ${ }^{a, *}$, C. M. Costa ${ }^{a}$, J. V. Emerenciano Neto ${ }^{b}$, J. G. \\ Rodrigues $^{c}$, A. B. G. Costa ${ }^{a}$, M. G. Pereira ${ }^{c}$, \& L. C. V. Ítavo ${ }^{a}$ \\ aFaculty of Veterinary Medicine and Animal Science, Federal University of Mato Grosso \\ Av. Senador Felinto Muller, 2443, CEP: 79070-900, Campo Grande, MS, Brazil \\ ${ }^{\mathrm{b}}$ Campus of Agricultural Sciences, Federal University of Vale do São Francisco, Brazil \\ 'Specialized Unit in Agricultural Sciences, Federal University of Rio Grande do Norte, Brazil \\ *Corresponding author: antonioleandro09@gmail.com \\ (Received 13-12-2019; Revised 04-02-2020; Accepted 06-03-2020)
}

\begin{abstract}
Identifying forage species that are responsive in regions with marked water deficits is one of the greatest challenges for the sustainable development of agriculture. However, information is still lacking about the persistence response of those pastures and their abilities to produce new tissues at the times of water scarcity. We hypothesized that Brachiaria grass has a tillering capacity during water-stress periods. This study thus examined the tillering capacity and structural characteristics of four Brachiaria brizantha cultivars (Xaraés, Piatã, Marandu, and Paiaguás) and one Brachiaria decumbens cultivar (Basilisk) in the Brazilian semi-arid region during the dry season (September to March). The experiment was laid out in a randomized block design with repeated measures over time in which five treatments were tested in four replicates. Tillering parameters, pasture production, and structural variables were evaluated. There was no interaction effect of cultivar $\times$ evaluation period on the tiller appearance $(p=0.1774)$, mortality $(p=0.1952)$ or survival $(p=0.4469)$ rates. The highest tiller appearance and mortality rates were observed in Marandu, while the highest survival rates were found in Marandu and Paiaguás. The index of tiller population stability was higher than or equal to 1.0 in all cultivars. Cultivar Basilisk showed the highest herbage mass yield $\left(4448.0 \mathrm{~kg} \mathrm{DM} \mathrm{ha}^{-1}\right)$, whereas Basilisk exhibited the highest yields of leaf (1845.9 $\left.\mathrm{kg} \mathrm{DM} \mathrm{ha}^{-1}\right)$, stem $\left(1676.9 \mathrm{~kg} \mathrm{DM} \mathrm{ha}^{-1}\right)$, and dead material (925.2 $\mathrm{kg} \mathrm{DM} \mathrm{ha}^{-1}$ ). The highest leaf:stem ratio (1.8) was found in Marandu. Cultivar Xaraés had the highest canopy $(70.8 \mathrm{~cm})$. The B. brizantha and B. decumbens cultivars evaluated in this study have the potential for cultivation in areas with marked water deficits, as is the case of the Brazilian semi-arid region. Cultivars Marandu, Basilisk, and Paiaguás exhibited the greatest tillering dynamics as well as the highest herbage-mass yield.
\end{abstract}

Keywords: Brachiaria brizantha; Brachiaria decumbens; forage; tillering dynamics; tropical grassland

\section{INTRODUCTION}

Native to Africa, the genus Brachiaria was widespread in Brazil and became the most widely used grass in pasture-based production systems (Luna et al., 2016). Its cultivation on Brazilian soils has been ascribed to its adaptability to low-fertility conditions, tolerance to drought stress, and high herbage-mass potential (Luna et al., 2016). Coupled with low adoption of cultivated pastures by the farmers, the irregular rainfall in the Brazilian semi-arid region (Emerenciano Neto et al., 2011) has accelerated the deforestation process in the Caatinga biome (Pereira et al., 2019). This condition is because native pastures, the major roughage source, are practically unmanaged, which heightens the need to intensify animal production through the use of cultivated pastures (Nunes et al., 2017).
Therefore, identifying forage species that are responsive in regions with marked water deficits is one of the greatest challenges for the sustainable development of agriculture (Nunes et al., 2017). In this respect, some researchers (Emerenciano Neto et al., 2013; Luna et al., 2014; Emerenciano Neto et al., 2014; Oliveira et al., 2019; Sousa et al., 2019; Souza et al., 2019) evaluated Brachiaria grass cultivars as an alternative forage for animal production in semi-arid regions and obtained promising results. However, information is still lacking about the persistence response of those pastures and their abilities to produce new tissues at the times of water scarcity.

Tillering is dependent on soil water balance, water-holding capacity, and fertility as well as light interception, solar radiation, and ambient temperature (Montagner et al., 2012; Sousa et al., 2019). The limitations to one or more of these factors may be present 
during the dry season, which would restrict regrowth capacity and, consequently, herbage production. Together with the accumulation of nutrient reserves in the plant, these conditions improve the regrowth capacity of pasture. Therefore, it is important to understand the dynamics of plant population by investigating the changes in the tiller density, survival, and mortality parameters so that management practices can be defined to ensure the longevity, productivity, and sustainability of the pasture throughout the year (Sousa et al., 2019).

The hypothesis tested in this study was that Brachiaria grass has tillering capacity during water-stress periods. Thus, we examined the tillering capacity and structural characteristics of four Brachiaria brizantha cultivars (Xaraés, Piatã, Marandu, and Paiaguás) and one Brachiaria decumbens cultivar (Basilisk) in the Brazilian semi-arid region during dry season (September to March).

\section{MATERIALS AND METHODS}

\section{Experimental Location and Soil-Climate Monitoring}

The experiment was conducted in an experimental area of the Forage Crops Research Group of the Federal University of Rio Grande do Norte - UFRN, in Macaíba - RN, Brazil, from September 2016 to March $2017\left(5^{\circ} .53^{\prime} 35.12^{\prime \prime}\right.$ S, 35 $21^{\prime} 47.03^{\prime \prime}$ W, $11 \mathrm{~m}$ above sea level). The climate of the region is a hot and dry semiarid BSh'W type, according to the Köppen classification, with water surplus occurring from May to August (Thorthwaite, 1948). A pluviometer was installed in the experimental area to measure the climatic data. Temperature and evapotranspiration data were obtained from the platform of the National Institute of Meteorology. The soil water balance (Figure 1) was calculated by the method of Thorthwaite (1948), adopting a soil water holding capacity of $25 \mathrm{~mm}$.

The soil in the area is classified as a Quartzipsamment. At the onset of the experiment, soil chemical analyses were performed at the depths of 0-20 and 20-40 $\mathrm{cm}$ (Table 1). Based on the results, $500 \mathrm{~kg} \mathrm{ha}^{-1}$ dolomitic limestone, $105 \mathrm{~kg} \mathrm{ha}^{-1} \mathrm{P}_{2} \mathrm{O}_{5^{\prime}} 164 \mathrm{~kg} \mathrm{ha}^{-1} \mathrm{~K}_{2} 0$, and $100 \mathrm{~kg} \mathrm{ha}^{-1} \mathrm{~N}$ were applied in split doses: once at 42 days after sowing and another following the plotuniformity cut (50 $\mathrm{kg} \mathrm{ha}^{-1} \mathrm{~N}$ each).

\section{Experiment}

The experiment was laid out in a randomized block design with repeated measures over time (six harvests) in which five treatments were tested in four replicates. Treatments were represented by the B. brizantha cultivars Xaraés, Piatã, Marandu, and Paiaguás and $B$. decumbens cultivar Basilisk.

The experimental area consisted of $750 \mathrm{~m}^{2}$, with 20 plots divided into four blocks. Each block was composed of five subplots, with $1.0 \mathrm{~m}$ spacing between subplots and $2.0 \mathrm{~m}$ between blocks. The plots measured $4.0 \mathrm{~m}^{2}(2.0 \mathrm{~m} \times 2.0 \mathrm{~m})$, containing a usable area of $1.3 \mathrm{~m}^{2}$, and $0.70 \mathrm{~m}^{2}$ of each side were considered as a bordering area. The cultivars were planted in April 2016. After planting, a 110-day period was used for plant establishment during which only manual invasive plant control was carried out, until the start of data collection. Sowing density was calculated considering the recommendations for each cultivar and the crop value (\%) of the seeds. The plot-uniformity cut was made at $15 \mathrm{~cm}$ above soil level, at 110 days after sowing.

\section{Tiller Population Dynamics}

The dynamics of tiller population were evaluated monthly in three tussocks marked in each experimental unit. In the first evaluation, all the tillers from each tussock were marked with wires of the same color, and these were considered as the first generation. The steps of tiller marking and counting were repeated in each evaluation, and new tillers were marked with different colors to identify new generations. The tillers were dis-

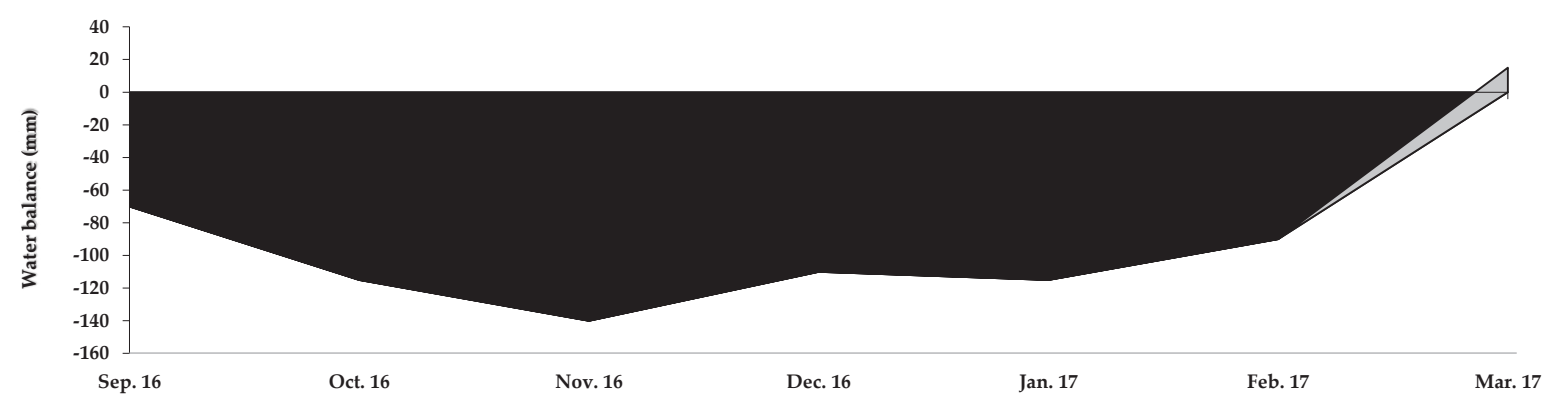

Figure 1. Soil water balance during the experimental period; $\mathbf{\square}=$ deficiency; $\square$ = excess.

Table 1. Chemical characteristics of the soil in the experimental area at the depths of $0-20$ and $20-40 \mathrm{~cm}$

\begin{tabular}{|c|c|c|c|c|c|c|c|c|c|c|c|c|c|}
\hline \multirow{2}{*}{$\begin{array}{c}\text { Layer } \\
(\mathrm{cm})\end{array}$} & $\mathrm{P}$ & K & $\mathrm{Na}$ & \multirow{2}{*}{$\begin{array}{c}\mathrm{pH} \\
\mathrm{H}_{2} \mathrm{O}\end{array}$} & $\mathrm{Ca}$ & $\mathrm{Mg}$ & $\mathrm{Al}$ & $\mathrm{H}+\mathrm{Al}$ & CEC & \multirow{2}{*}{ BS (\%) } & \multicolumn{3}{|c|}{ Particle size (\%) } \\
\hline & & $\mathrm{g} \mathrm{dm}$ & & & \multicolumn{5}{|c|}{ cmolc dm ${ }^{-3}$} & & Sand & Silt & Clay \\
\hline $0-20$ & 18.0 & 63.0 & 20.0 & 6.6 & 3.1 & 0.2 & - & 1.2 & 4.4 & 72.7 & 84.6 & 4.0 & 11.4 \\
\hline $20-40$ & 8.0 & 49.0 & 13.0 & 5.6 & 0.9 & 0.1 & - & 1.1 & 2.2 & 50.0 & 85.2 & 2.0 & 12.8 \\
\hline
\end{tabular}

Note: $\mathrm{CEC}=$ cation-exchange capacity, $\mathrm{BS}=$ base saturation. 
tinguished in every generation in terms of growth-bud location (basal and aerial tillers). Dead tillers were also counted in each generation.

Based on this data, the following variables were calculated, as proposed by Bahmani et al. (2003):

Tiller appearance rate $(\mathrm{TAR})=$

The number of new tillers (last marked generation)/total existing tillers (previously marked generation) $\times 100$;

Tiller mortality rate $(\mathrm{TMR})=$

The number of previously marked tillers - surviving tillers (current count)/total number of tillers in the previous marking $\times 100$;

The tiller population stability index $\left(\mathrm{P}_{1} / \mathrm{P}_{0}\right)$ was calculated by the following equation: $\mathrm{P}_{1} / \mathrm{P}_{0}=\mathrm{TSR}(1+\mathrm{TAR})$, where TSR (tiller survival rate) $=1-\mathrm{TMR}$.

\section{Herbage Mass and Morphological Components}

Herbage mass was estimated by cutting the grass at $15 \mathrm{~cm}$ above the soil level and weighing all the herbage within a $1.0 \mathrm{~m}^{2}$ square frame. Subsequently, a subsample was removed and weighed to determine the fresh weight and then dried in a forced-air oven at $55^{\circ} \mathrm{C}$ for 72 $\mathrm{h}$ to determine the dry matter content (AOAC, 2005).

The remainder of the sample was used for the separation of the morphological components into leaf, stem (stem + sheath), and dead material. These components were oven-dried in the same way as the herbage mass. The dry weight of each sample fraction was then used to estimate the dry matter content and to calculate the masses of leaf, stem, and dead material. Subsequently, the leaf:stem ratio was calculated.

\section{The Height of Canopy}

The height of the canopy was measured using a centimeter-graduated ruler at three random points per plot, before each harvesting. The height of each point corresponded to the height of the average curvature of the leaves in the canopy around the ruler.

\section{Light Interception (LI)}

The light interception was estimated before each harvesting, using a canopy analyzer (AccuPAR Linear PAR/LAI ceptometer, Model PAR -80; DECAGON Devices $^{\circledR}$ ). In each evaluation, eight readings were taken above the canopy and three readings at the soil level, in each experimental plot, between 10.00 and 12.00. The following formula was used for the calculation: \% LI= 100\% - (Soil level/Above soil × 100) (Montagner et al., 2012).

\section{Tiller Density}

Tiller density (TD, tillers $/ \mathrm{m}^{2}$ ) data were obtained by counting the number of basal and aerial tillers in a delimited area of each plot, using a $0.09-\mathrm{m}^{2}$ square frame.
To choose the sampling points, we considered the average condition of the plot at the time of evaluation. These areas were kept fixed throughout the evaluation period. The tillers were counted monthly.

\section{Statistical Analysis}

Analyses were performed using $\mathrm{R}$ software version 3.5.0 (R Development Core Team, 2016). Tiller appearance rate, TMR, and TSR data were subjected to the analysis of variance in a split-plot-in-time completely randomized block design.

In the analysis of structural variables of pasture, only the cultivar was considered as a fixed effect. When significant by the F test, the effects of sources of variation and their interactions were checked by Tukey's test at the $5 \%$ significance level.

Correlations were obtained by Pearson's correlation analysis and the t-test, considering significance at $p<0.05$. The criterion for the classification of the correlation coefficient was $r \geq 80 \%$ meaning a strong correlation and $50 \%<r \leq 70 \%$ indicating a moderate correlation.

\section{RESULTS}

\section{Tiller Population Dynamics}

The dynamics of the tiller population were evaluated for seven generations. The highest number of tillers was observed in the first generation, regardless of the cultivar. Cultivar Basilisk showed the highest number of tillers in the first and the second generations (Figure 2). The fourth-generation had the lowest tillering values, and the greatest vigor was found in cultivar Piatã. The number of tillers increased from the fourth generation onwards; this was especially true for the seventh generation, even though the tillers were less vigorous than those in the first and the second generations. In the last generation, cultivar Paiaguás showed the largest tiller population.

There was no interaction effect of cultivar $\times$ evaluation period for the tiller appearance $(p=0.1774)$, mortality $(p=0.1952)$, or survival $(p=0.4469)$ rates. The highest TAR was observed in cultivar Marandu, whereas the other cultivars did not differ for this variable (Figure 3). Mortality was higher in Marandu than in Paiaguás, Basilisk, and Xaraés, while Piatã showed an intermediate TMR (Figure 3). The highest tiller appearance and mortality rates were recorded on days 28 (Figures 3 and 4).

Cultivars Marandu and Paiaguás showed higher TSRs $(p=0.0080)$ than cultivars Xaraés and Basilisk. Cultivar Piatã, in turn, showed an intermediate TSR (Figure 5). When the survival rate was evaluated as a function of the experimental period, the lowest value was seen on 28 days, whereas the highest was found in 185 days. Tiller density was higher than or equal to 1.0 for all cultivars throughout the experimental period, indicating that TAR was always higher than TMR (Figure 6). 
Xaraés

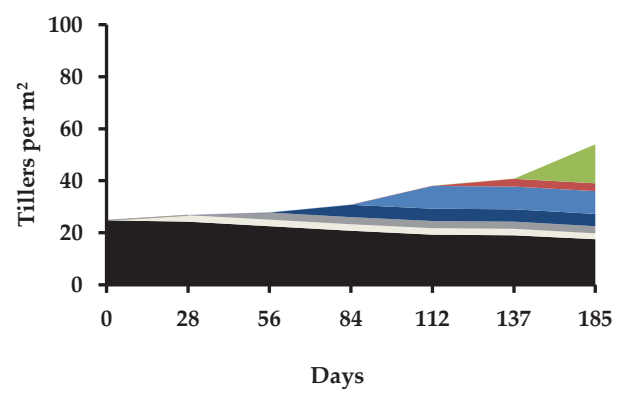

Piatã

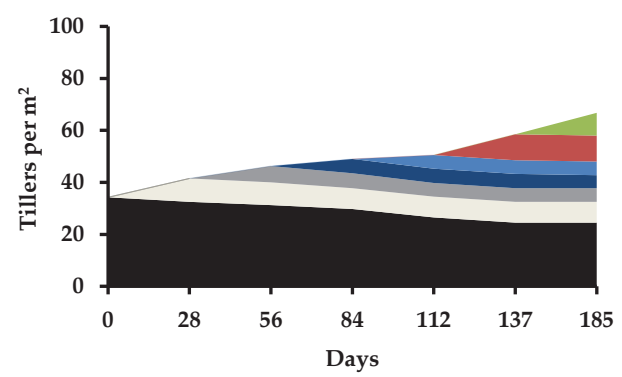

Paiaguás

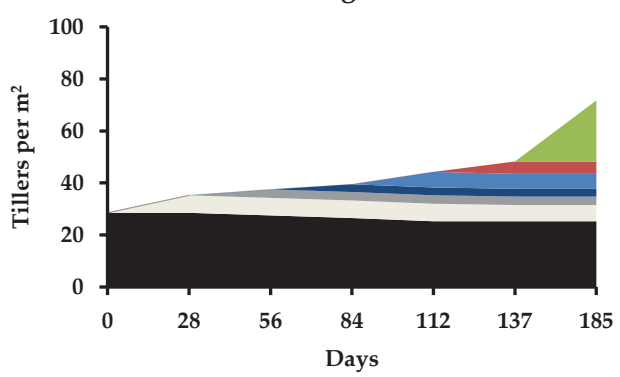

Basilisk

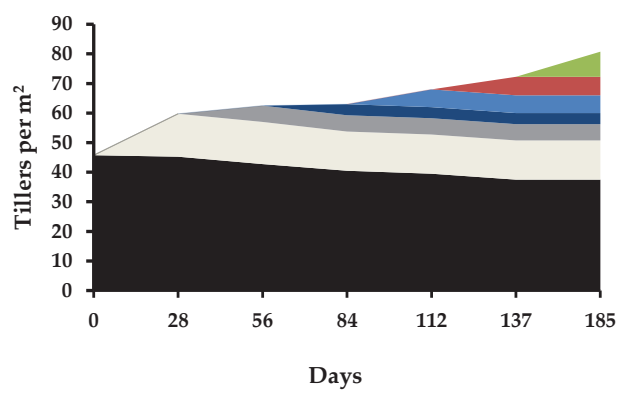

Marandu

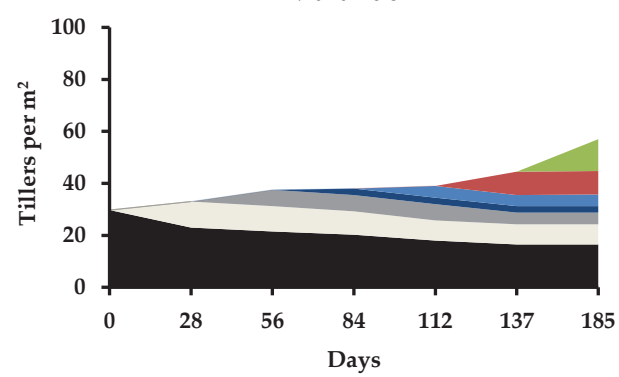

Figure 2. Tiller population dynamics of Brachiaria cultivars in the Brazilian semi-arid region; $\square=1^{\text {st }}$ Generation; $\square=2^{\text {nd }}$ Generation; $\square=3^{\text {rd }}$ Generation; $\square=4^{\text {th }}$ Generation; $\square=5^{\text {th }}$ Generation; $\square=6^{\text {th }}$ Generation; $\square=7^{\text {th }}$ Generation.
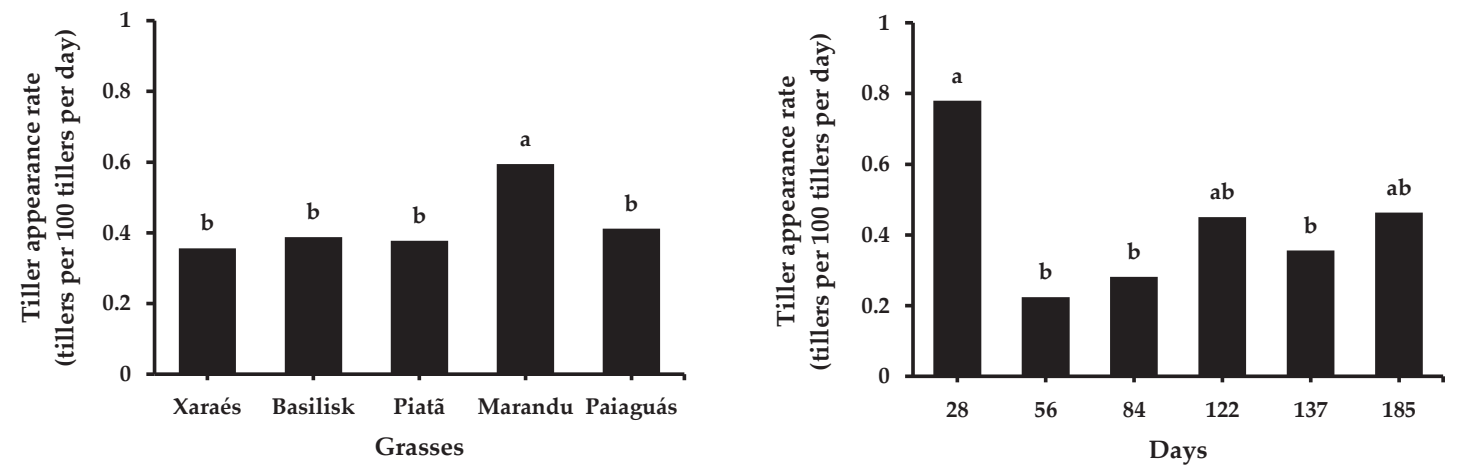

Figure 3. Tiller appearance rate of Brachiaria cultivars in the Brazilian semi-arid region

\section{Yields of Herbage and Morphological Components, LI, and TD}

The highest yields of herbage and leaf were found in Basilisk and the lowest in Piatã and Paiaguás, even though no statistical difference was detected between the cultivars (Table 2). The highest yields of stems and dead material were observed in Basilisk, and the lowest in Marandu, Piatã, and Paiguás. Cultivar Xaraés, in turn, was intermediate for these variables. The leaf:stem ratio in Marandu was higher than that measured in Basilisk and Xaraés, and intermediate values were shown by Piatã and Paiaguás. Cultivar Xaraés had a higher canopy than Marandu and Paiaguás. No significant difference in canopy height was detected for Basilisk and Piatã. Tiller density differed between the cultivars; the high- 

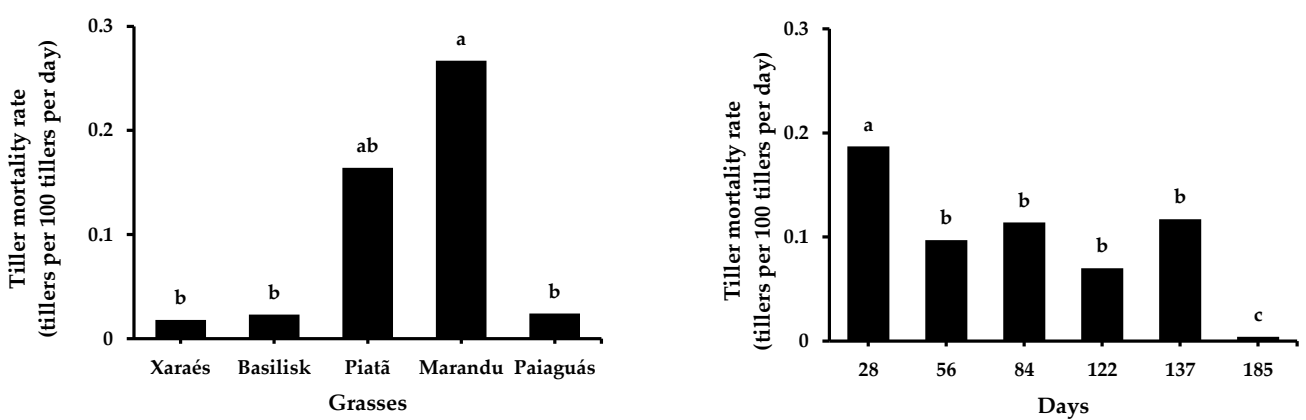

Figure 4. Tiller mortality rate of Brachiaria cultivars in the Brazilian semi-arid region
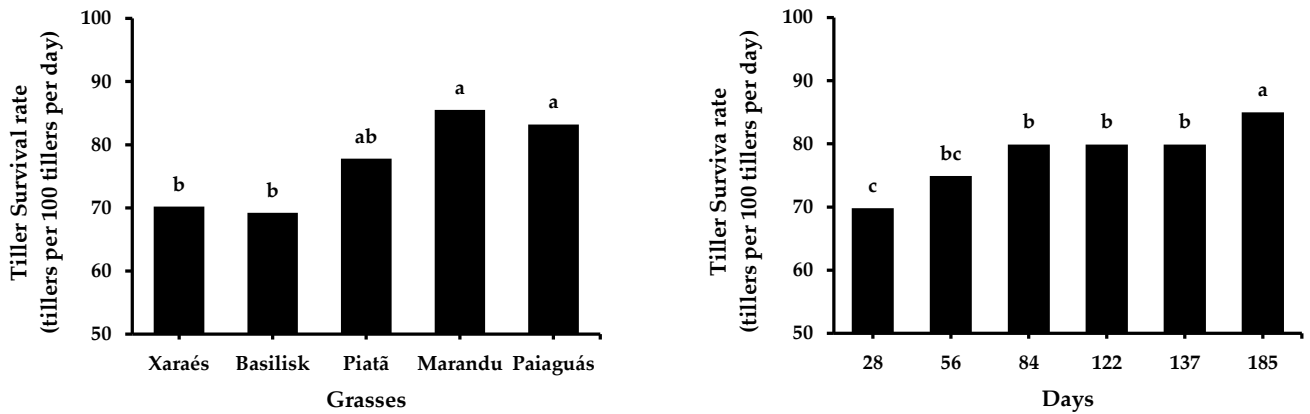

Figure 5. Tiller survival rate of Brachiaria cultivars in the Brazilian semi-arid region
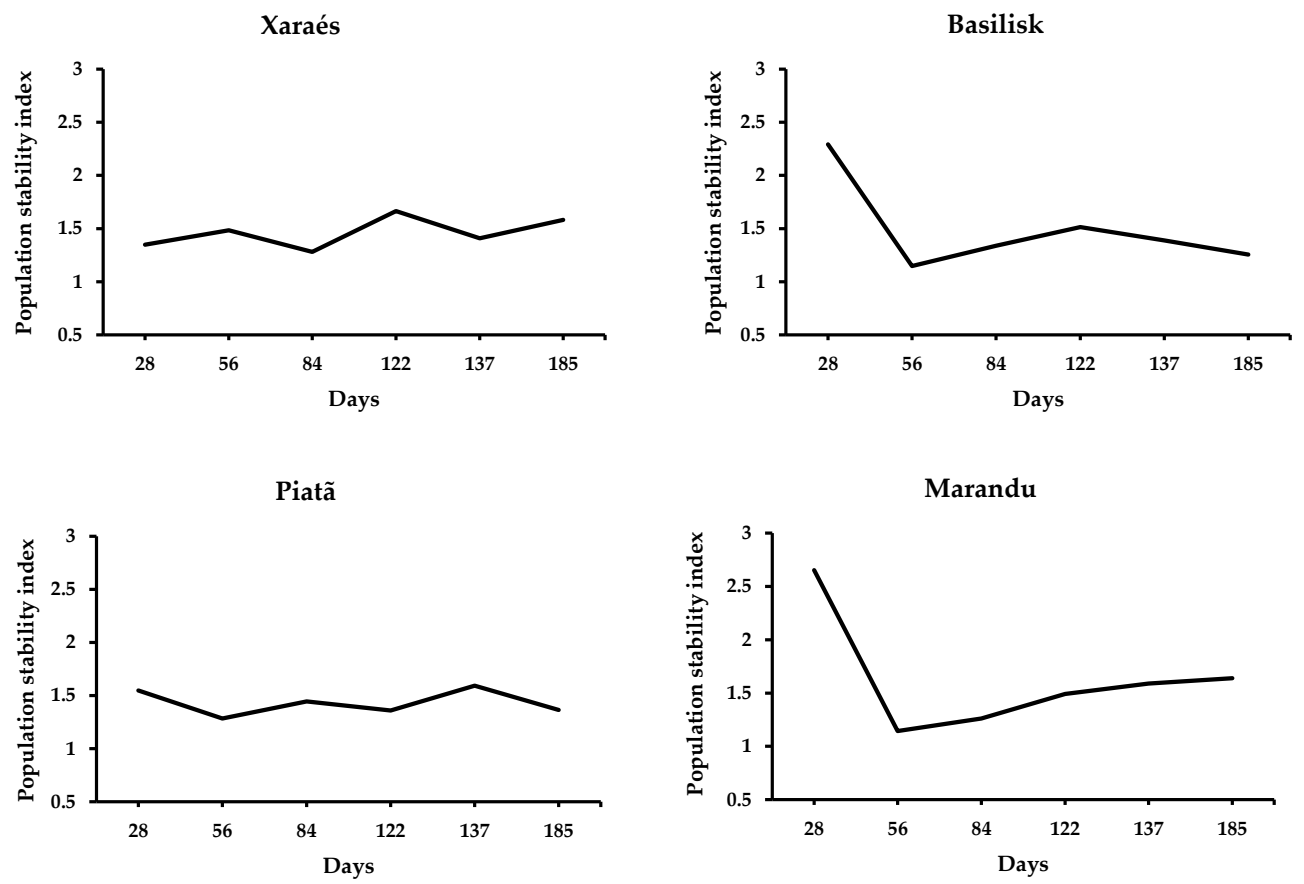

Paiaguás

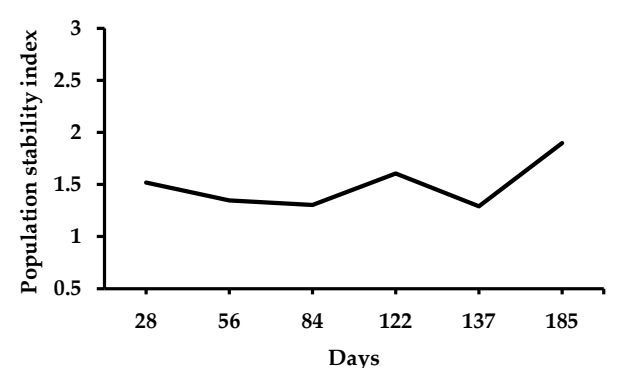

Figure 6. Tiller population stability index of Brachiaria cultivars in the Brazilian semi-arid region 
Table 2. Structural characteristics of Brachiaria cultivars grown in the Brazilian semi-arid region

\begin{tabular}{|c|c|c|c|c|c|c|c|}
\hline \multirow{2}{*}{ Variables } & \multicolumn{5}{|c|}{ Cultivar } & \multirow{2}{*}{ SEM } & \multirow{2}{*}{$\mathrm{p}$-value } \\
\hline & Basilisk & Marandu & Paiaguás & Piatã & Xaraés & & \\
\hline HM (kg DM ha-1) & $4448.0^{\mathrm{a}}$ & $2450.7^{\mathrm{ab}}$ & $1762.4^{\mathrm{b}}$ & $1813.6^{\mathrm{b}}$ & $2954.3^{\mathrm{ab}}$ & 500.7 & 0.0305 \\
\hline LY $($ kg DM ha-1) & $1845.9^{a}$ & $1249.9^{\mathrm{ab}}$ & $747.3^{\mathrm{b}}$ & $736.3^{b}$ & $1.409 .2^{\mathrm{ab}}$ & 206.0 & 0.0671 \\
\hline SY $($ kg DM ha-1) & $1676.9^{a}$ & $696.0^{\mathrm{b}}$ & $576.3^{\mathrm{b}}$ & $582.2^{\mathrm{b}}$ & $839.0^{\mathrm{ab}}$ & 107.0 & 0.0134 \\
\hline DMY (kg DM ha-1) & $925.2^{\mathrm{a}}$ & $504.8^{\mathrm{b}}$ & $438.8^{b}$ & $495.1^{b}$ & $706.1^{\mathrm{ab}}$ & 94.2 & 0.0254 \\
\hline $\mathrm{L}: \mathrm{S}$ & $1.1 b$ & $1.8^{\mathrm{a}}$ & $1.3^{\mathrm{ab}}$ & $1.3^{\mathrm{ab}}$ & $2.0^{\mathrm{a}}$ & 0.18 & 0.0085 \\
\hline TD (tillers/m²) & $381.7^{\mathrm{a}}$ & $206.9^{b}$ & $232.2^{\mathrm{ab}}$ & $276.63^{\mathrm{ab}}$ & $215.19^{\mathrm{ab}}$ & 25.7 & 0.036 \\
\hline Height (cm) & $54.6^{\mathrm{ab}}$ & $48.3^{\mathrm{b}}$ & $48.2^{\mathrm{b}}$ & $60.1^{\mathrm{ab}}$ & $70.8^{\mathrm{a}}$ & 4.6 & 0.0236 \\
\hline LI (\%) & 90.4 & 81.8 & 80.2 & 90.1 & 92.4 & 5.9 & 0.5043 \\
\hline
\end{tabular}

Note: Means in the same row with different superscripts differ significanty $(\mathrm{p}<0.05)$. SEM= standard error of the mean, HM= herbage mass, LY= leaf yield, SY= stem yield, DMY= dead material yield, L:S= leaf:stem ratio, TD= tiller density, LI= light interception.

est values were observed in Basilisk and the lowest in Marandu. No cultivar effect was detected for LI. The main variables that showed significant correlations $(p<0.05)$ of moderate to high magnitude are presented in Table 3.

\section{DISCUSSION}

\section{Tiller Population Dynamics}

The first generation corresponded to the number of tillers at various ages present on the first marking date. Because the dates of their appearances could not be identified, this generation was more numerous, regardless of the cultivar. This result might have also been further increased by the nitrogen fertilization applied following the uniformity cut. The higher number of tillers observed in the generations of Basilisk may be attributed to the different species used (B. brizantha and $B$. decumbens), which normally exhibit different tiller growth and development patterns (Nkugu et al., 2016).

The fourth tiller generation was the least numerous because the evaluation coincided with the period of lowest precipitation, which resulted in the highest soil water deficit (Figure 1). In this condition, the plant metabolism is slowed, and, consequently, so are the processes involved in the emergence of new tillers (Luna et al., 2014). The increased tillering observed in the seventh generation may be attributed to the resumption of the rainy period, which was the only period when the soil was under a positive water balance (Figure 1). Euclides et al. (2019) stress that water availability in the soil is a decisive factor for a more intense morphogenesis process, whereby new plant tissues and structures are originated.

The observed differences in tiller appearance and mortality rates reveal the intense dynamics of tissue turnover in B. brizantha cultivar Marandu, given its high appearance and mortality rates. The application of nitrogen fertilizer following the uniformity cut might have stimulated tillering in the pastures at 28 days, considering the effect of nitrogen on the metabolism of forage plants (Basso et al., 2010; Pitmam, 2012), which intensifies the tiller emergence and senescence processes.

Cultivar Paiaguás showed the high tiller survival indices, despite the low appearance rates. This cultivar has a great survival potential in the dry season (Valle et al., 2013) in semi-arid environments. Plant survival is just as important as herbage production potential, as it prevents the need for constantly re-sowing the same area. In regional experiments, when compared to Piatã, which was released as an alternative for the dry season, Paiaguás exhibited an even greater potential by virtue of its higher herbage accumulation capacity (Euclides et al., 2016). Cultivar Paiaguás was the most responsive at the beginning of the rainy period, showing the highest

Table 3. Linear correlations between structural traits of forage grasses

\begin{tabular}{|c|c|c|c|c|c|c|c|c|c|c|}
\hline & $\mathrm{HM}$ & LY & SY & L:S & $\mathrm{TD}$ & Height & LI & TAR & TMR & TSR \\
\hline $\mathrm{HM}$ & 1.00 & - & - & - & - & - & - & - & - & - \\
\hline LY & $0.37^{*}$ & 1.00 & - & - & - & - & - & - & - & - \\
\hline SY & $0.32^{*}$ & $-0.73^{*}$ & 1.00 & - & - & - & - & - & - & - \\
\hline L:S & $0.12^{\mathrm{NS}}$ & $0.41^{*}$ & $-0.89^{*}$ & 1.00 & - & - & - & - & - & - \\
\hline TD & $0.61^{*}$ & $0.80^{*}$ & $0.65^{*}$ & $0.12^{\mathrm{NS}}$ & 1.00 & - & - & - & - & - \\
\hline Height & $0.44^{*}$ & $0.07^{\mathrm{NS}}$ & $0.71^{*}$ & $0.19^{\mathrm{NS}}$ & $-0.59^{*}$ & 1.00 & - & - & - & - \\
\hline LI & $0.41^{*}$ & $0.67^{*}$ & $0.32^{*}$ & $0.01^{\mathrm{NS}}$ & $-0.76^{*}$ & $0.81^{*}$ & 1.00 & - & - & - \\
\hline TAR & $0.38^{*}$ & $0.57^{*}$ & $0.82^{*}$ & $0.03^{\mathrm{NS}}$ & $0.82^{*}$ & $0.13^{\mathrm{NS}}$ & $0.02^{\mathrm{NS}}$ & 1.00 & - & - \\
\hline TMR & $0.20^{\mathrm{NS}}$ & $-0.19^{\mathrm{NS}}$ & $0.71^{*}$ & $0.08^{\mathrm{NS}}$ & $-0.73^{*}$ & $0.09^{\mathrm{NS}}$ & $0.08^{\mathrm{NS}}$ & $0.36^{*}$ & 1.00 & - \\
\hline TSR & $0.90^{*}$ & 0.15 & $0.51^{*}$ & $0.07^{\mathrm{NS}}$ & $0.63^{*}$ & $0.01^{\mathrm{NS}}$ & $0.12^{\mathrm{N} S}$ & $-0.33^{*}$ & $-0.91^{*}$ & 1.00 \\
\hline
\end{tabular}

Note: $\mathrm{NS}=$ Not significant, ${ }^{*}=(\mathrm{p}<0.05)$. HM= herbage mass, $\mathrm{LY}=$ leaf yield, $\mathrm{SY}=$ stem yield, $\mathrm{L}: \mathrm{S}=$ leaf:stem ratio, $\mathrm{TD}=$ tiller density, $\mathrm{LI}=$ light interception, $\mathrm{TAR}=$ tiller appearance rate, $\mathrm{TMR}=$ tiller mortality rate, $\mathrm{TSR}=$ tiller survival rate. 
tiller population in the last generation (Figure 2). In the semi-arid region, where the rainy period is short, the more responsive a cultivar is, the longer will be the time of pasture usability in the production system, a characteristic that is even more marked in Paiaguás.

Despite the higher tiller appearance and mortality rates, the lowest survival rates were detected at 28 days, which was a result of the compensatory mechanism for the maintenance of balance in the tiller population and increased tissue turnover. As the plant grows, intraspecific competition for light gradually increases, reducing the quantity and quality of light that enters the canopy and leading to morphophysiological changes in the plant (Santo et al., 2010a; Montagner et al., 2012) This compensatory mechanism has a direct impact on tiller survival (Sousa et al., 2019).

Overall, the cultivars showed a stable condition, with stability indices higher than or equal to 1.0 and no drastic increases or decreases in tiller population. This fact suggests high adaptability of these cultivars to semi-arid environments, as were verified by the survival and even emergence of new tillers in a water-stressed environment. The stability values of the tiller population lower than 1.0 indicate low stability, with considerable fluctuations in the number of tillers. Additionally, stability rates below 1.0 indicate that the appearance of new tillers is not sufficient to offset the mortality rates and, as a consequence, the population tends to decrease over time (Sousa et al., 2019; Euclides et al., 2016; Bahmani et al., 2003).

\section{Yields of Herbage and Morphological Components, LI, and TD}

Cultivar Basilisk showed the highest TD, which was a result of its higher TAR (Figure 2). By contrast, the lowest TD found in Marandu was a consequence of the higher mortality rates observed in this cultivar. Cultivars with a high TD are advantageous since tillers are essential for pasture persistence due to their better efficiencies in utilizing resources such as water, nutrients, and light.

The higher yields of herbage and morphological components found in Basilisk may be explained by the higher tiller population dynamics shown by that cultivar-in the first generations, mainly (Figure 2)-and by the association between tiller density and herbage yield (Montagner et al., 2012; Luna et al., 2016). In semiarid regions, where roughage availability is typically low, a greater focus should be placed on cultivars with a greater capacity to produce forage under such conditions. The lower leaf:stem ratio observed in the Basilisk pastures is a result of the higher proportion of stems in the herbage mass of that cultivar.

Cultivar Xaraés had the highest canopy among the Brachiaria cultivars, as also observed by Luna et al. (2014) and Silveira et al. (2010), who compared groups of forage cultivars of the genus. However, none of the cultivars reached the critical leaf area index, a condition in which the pasture intercepts $95 \%$ of the incident light (Echeverria et al., 2016). Therefore, there was no compe- tition for the light at the base of the plant, which might inhibit tillering.

Tiller density increases proportionally to tiller appearance rate. This relationship has a direct impact on herbage accumulation, culminating in higher masses of leaf and stem. In tropical pastures, morphogenetic traits (leaf appearance and elongation rates, leaf lifespan, and stem elongation rate) dictate the tillering dynamics and determine structural responses, which explain the above-described phenomenon (Difante et al., 2011).

The negative correlation between the masses of leaf and stem is a result of stem elongation, which provides shading, and the death of older leaves (Santos et al., $2010 b)$. Thus, the negative correlations between stem mass and leaf:stem ratio were also consistent. Tiller density is inversely correlated with height and light interception, which is attributed to the compensatory mechanism between tiller size and density (Santos et al., 2010a) whereby lower pastures have a higher number of short tillers, unlike taller pastures, where a lower population of heavy tillers is found.

\section{CONCLUSION}

Brachiaria brizantha cvs. Xaraés, Piatã, Marandu, and Paiaguás as well as Brachiaria decumbens cv. Basilisk have potential to be cultivated in areas with marked water deficits, such as the Brazilian semi-arid region. Greater emphasis should be placed on cvs. Marandu, Basilisk, and Paiaguás, given their tillering characteristics as well as higher herbage mass.

\section{CONFLICT OF INTEREST}

We certify that there is no conflict of interest with any financial, personal, or other relationships with other people or organization related to the material discussed in the manuscript.

\section{ACKNOWLEDGEMENT}

This research was funded by the Coordination for the Improvement of Higher Education Personnel - Brazil (CAPES) - Financing Code 001 and the National Council for Scientific and Technological Development (CNPq) and supported by the University of Rio Grande do Norte.

\section{REFERENCES}

AOAC. 2005. Official methods of analysis. 16th ed. Arlington, VA: Association of Official Analytical Chemists, International.

Bahmani, I., E. R. Thom, C. Matthew, R. J. Hooper, \& G. Lemaire. 2003. Tiller dynamics of perennial ryegrass cultivars derived from different New Zealand ecotypes: effects of cultivar, season, nitrogen fertilizer, and irrigation. Aust. J. Agric. Res. 54:803-817. https://doi.org/10.1071/AR02135

Basso, K. C., U. Cecato, S. M. B. Lugão, J. A. N. Gomes, L. M. Barbero, \& G. B. Mourão. 2010. Morfogênese e dinâmica do perfilhamento em pastos de Panicum maximum Jacq. cv. IPR-86 Milênio submetido a doses de nitrogênio. Rev. Bras. Saúde Prod. An. 11: 976-989. 
Difante, G. S., D. Nascimento Júnior, S. C. Silva, V. P. B. Euclides, D. B. Montagner, C. T. Silveira, \& K. S. Pena. 2010. Morphogenetic and structural characteristics of marandu palisadegrass subjected to combinations of cutting heights and cutting intervals. Rev. Bras. Zootecn. 40: 955963. https://doi.org/10.1590/S1516-35982011000500003

Echeverria, J. R., V. P. B. Euclides, A. F. Sbrissia, D. B. Montagner, R. A. Barbosa, \& N. N. Nantes. 2016. Forage accumulation and nutritive value of the Urochloa interspecific hybrid 'BRS RB331 Ipyporã' under intermittent grazing. Pesq. Agropec. Bras. 51: 880-889. https://doi. org/10.1590/S0100-204X2016000700011

Emerenciano Neto, J. V., G. S. Difante, E. M. Aguiar, L. S. Fernandes, H. C. B. Oliveira, \& M. G. T. Silva. 2014. Performance of meat sheep, chemical composition and structure of tropical pasture grasses managed under intermittent capacity. Biosci. J. 30:834-842.

Emerenciano Neto, J. V., G. S. Difante, D. B. Montagner, M. G. S. Bezerra, R. C. P. Galvão, \& R. I. G. Vasconcelos. 2013. Sward structural characteristics and herbage accumulation in tropical grasses, under intermittent stocking and sheep grazed. Biosci. J. 29:962-973.

Emerenciano Neto, J. V., G. F. Pereira, H. R. Medeiros, A. P. A. C. Gracindo, \& G. S. Difante. 2011. Caracterização e avaliação econômica de sistemas de produção de agricultura familiar no semiárido. Rev. Bras. Agropec. Sust. 1:21-28. https://doi.org/10.21206/rbas.v1i1.7.

Erasmo, E. A. L., R. C. Goncalves, J. F. Mata, V. A. Oliveira, \& L. P. F. Benicio. 2017. Growth of Brachiaria brizantha planted at different densities and seasons in Santa Fé systems with a culture of soybean. Emi. J. Food Agricul. 29:658-663. https://doi.org/10.9755/ejfa.2017.v29.i9.108

Euclides, V. P. B., D. B. Montagner, R. A. Barbosa, C. B. Valle, \& N. N. Nantes. 2016. Animal performance and sward characteristics of two cultivars of Brachiaria brizantha (BRS Paiaguás and BRS Piatã). Rev. Bras. Zootecn. 45:8592. https://doi.org/10.1590/S1806-92902016000300001

Euclides, V. P. B., D. B. Montagner, M. C. M. Macedo, A. R. Araújo, G. S. Difante, \& R. A. Barbosa. 2019. Grazing intensity affects forage accumulation and persistence of Marandu palisadegrass in the Brazilian savannah. Grass. Forage. Sci. 75:1-13. https://doi.org/10.1111/gfs.12422

Luna, A. A., G. S. Difante, D. B. Montagner, J. V. Emerenciano Neto, I. M. M. Araujo, \& L.S. Fernandes. 2016. Tillering dynamic and structural characteristics of tropical grasses under cutting management. Biosci. J. 32:1008-1017. https:// doi.org/10.14393/BJ-v32n4a2016-32944

Luna, A. A., G. S. Difante, D. B. Montagner, J. V. Emerenciano Neto, I. M. M. Araújo, \& L. E. C. Oliveira. 2014. Características morfogênicas e acúmulo de forragem de gramíneas forrageiras, sob corte. Biosci. J. 30:1803-1810.

Montagner, D. B., D. Nascimento Júnior, H. H. Vilela, B. M. L. Sousa, V. P. E. Euclides, S. C. Da Silva, \& M. N. Carloto. 2012. Tillering dynamics in pastures of guinea grass subjected to grazing severities under intermittent stocking. Rev. Bras. Zootecn. 41:544-549. https://doi.org/10.1590/ S1516-35982012000300010

Nkugu, S. A., D. N. Njarui, N. K. R. Musimba, D. Amwata, \& E. M. Kaindi. 2016. Primary production variables of Brachiaria grass cultivars in Kenya drylands. Trop. Sub. Agroec. 19:29-39.
Nunes, A. T., D. L. V. Cabral, E. L. C. Amorim, M. V. F. Santos, \& U. P. Albuquerque. 2016. Plants used to feed ruminants in semi-arid Brazil: A study of nutritional composition guided by local ecology knowledge. J. Arid Environ. 135:96-103. https://doi.org/10.1016/j.jaridenv.2016.08.015

Oliveira, J. S., J. V. Emerenciano Neto, R. S. Santos, B. R. S. Bonfim, F. N. Lista, V. A. Vieira, \& G. S. Difante. 2019. Structural and Productive Characteristics of Urochloa Cultivars Submitted to Different Defoliation Frequencies in Semiarid Region. J. Agric. Stud. 7:91-102. https://doi. org/10.5296/jas.v7i3.15177

Pereira, G. F., J. V. Emerenciano Neto, G. S. Difante, C. S. L. Cortes, \& P. O. Lima. 2019. Morphogenic and structural characteristics of tropical forage grasses managed under different regrowth periods in the Brazilian semiarid region. Semin.-Cienc. Agrar. 40:283-292. https://doi. org/10.5433/1679-0359.2019v40n1p283

Pitman, W. D. 2012. Bahiagrass (Paspalum notatum Flugge) management combining nitrogen fertilizer rate and defoliation frequency to enhance forage production efficiency. Grass. Forage. Sci. 68:479-484. https://doi.org/10.1111/ gfs. 12005

Santos, M. E. R., D. M. Fonseca, I. M. Oliveira, D. R. Casagrande, E. M. Balbino, \& F. P. Freitas. 2010a. Correlações entre número de perfilhos, índice de tombamento, massa dos componentes morfológicos e valor nutritivo da forragem em pastos diferidos de capimbraquiária. Rev. Bras. Zootecn. 39:487-493. https://doi. org/10.1590/S1516-35982010000300006

Santos, M. E. R, D. M. Fonseca, E. M. Balbino, V. M. Gomes, \& S. P. Silva. 2010b. Correlations among structural characteristics and nutritional value of tillers on deferred and nitrogen-fertilized signalgrass pastures. Rev. Bras. Saúde Prod. An. 11:595-605.

Silveira, M. C. T., D. Nascimento Junior, S. C. Da Silva, V. P. B. Euclides, D. B. Montagner, \& A. F. Sbrissia. 2010. Morphogenetic and structural comparative characterization of tropical forage grass cultivars under free growth. Sci. Agric. 7:136-142. https://doi.org/10.1590/ S0103-90162010000200002

Sousa, B. M. L., C. A. Rizato, J. L. Fagundes, P. T. N. Fontes, A. A. Backes, L. F. G. Oliveira Junior, \& C. S. Nascimento. 2019. Tillering dynamics of digit grass subject to different defoliation frequencies. Pesqui. Agropecu. Bras. 54:1-9. https://doi.org/10.1590/s1678-3921.pab2019.v54.00668

Souza, J. S., G. S. Difante, J. V. Emerenciano Neto, A. M. Q. Lana, F. F. S. Roberto, \& P. H. C. Ribeiro. 2019. Biometric measurements of Santa Inês meat sheep reared on Brachiaria brizantha pastures in Northeast Brazil. PLOS ONE, 30:116. https://doi.org/10.1371/journal.pone.0219343

Thorthwaite, C. W. 1948. An approach toward a rational classification of climate. Geog. Rev. 1:55-93. https://doi. org $/ 10.2307 / 210739$

Valle, C.B., V. P. B. Euclides, D. B. Montagner, J. R. Valério, C. D. Fernandes, M. C. M Macedo, \& L. A. Z. Machado. 2013. Paiaguás: A new Brachiaria (Urochloa) cultivar for tropical pastures in Brazil. Trop. Grassl. 1:121-122. https:// doi.org/10.17138/TGFT(1)121-122 